\title{
Combinatorial Cytotoxic Effects of 2,3-Dichloro-5,8- dimethoxy-1,4-naphthoquinone and 4-hydroxytamoxifen in Triple-negative Breast Cancer Cell Lines
}

\author{
ANASTASIA G.J. ROBINSON ${ }^{1}$, YASMINE M. KANAAN ${ }^{2,3}$ and ROBERT L. COPELAND ${ }^{1,3}$ \\ ${ }^{1}$ Department of Pharmacology, College of Medicine, Howard University, Washington, DC, U.S.A.; \\ ${ }^{2}$ Department of Microbiology, College of Medicine, Howard University, Washington, DC, U.S.A.; \\ ${ }^{3}$ Cancer Center, Howard University, Washington, DC, U.S.A.
}

\begin{abstract}
Background/Aim: Triple-negative breast cancer $(T N B C)$ is a highly aggressive form of breast cancer (BC) and lacks targeted therapy and alternate therapeutic combinations. There is a necessity to increase disease-free survival in patients particularly within the first 5 years of diagnosis. 2,3-dichloro-5,8-dimethoxy-1,4-naphthoquinone (Z285), a novel 1,4 naphthoquinone analog, has been shown to have cytotoxic activity in BC cell lines and in combination with 4-hydroxytamoxifen (4-OHT). A known metabolite of tamoxifen, was postulated to decrease cell proliferation. Thus, this study investigates the use of Z285 and 4-OHT alone or in combination as a novel therapeutic alternative for TNBC. Materials and Methods: Cell proliferation assays were performed on MDA-MB-231, Hs578T, MCF7 and HCC1806 cell lines at varying time points with Z285 and 4OHT alone and in combination. Furthermore, ROS activity was measured to determine the changes in oxidative stress caused by both drugs. Results: The results showed dose- and time-dependent decreases in proliferation for all cell lines when treated with Z285, 4-OHT and their combination. Combinatorial analysis performed at $72 \quad h$ using Synergyfinder ${ }^{\circledR}$ showed additive effects in MCF7, HCC1806 and Hs578T and an antagonistic response in MDA-MB-231. Z285 caused a significant increase in ROS production in three cell lines after $8 \mathrm{~h}$, but HCC1806 showed no change in effect. Conclusion: These promising results suggest the independent ability of each compound as a stand-alone
\end{abstract}

This article is freely accessible online.

Correspondence to: R.L. Copeland, Department of Pharmacology, College of Medicine, Howard University, 520 W St NW, Suite 3408 Numa Adams Building, Washington DC 20059, U.S.A. Tel: +1 2028063861, Fax: +1 2027472721, e-mail: rlcopeland@howard.edu

Key Words: TNBC, tamoxifen, 1,4 naphthoquinone, breast cancer cell lines. chemotherapeutic agent, or in combinatorial therapy for the treatment of $T N B C$.

Triple-negative breast cancer (TNBC) lacks the expression of estrogen receptor $\alpha(\mathrm{ER} \alpha)$, progesterone receptor (PR) and human epidermal growth factor receptor 2 (HER2). The loss of these therapeutic targets limits the treatment options to chemotherapy, surgery, and radiation. This subtype accounts for $10-15 \%$ of diagnosed breast cancers (BC) but approximately $35 \%$ of metastatic BC-related deaths are attributed to TNBC (1). It is an aggressive phenotype and disproportionately effects African American (AA) women where the diagnosis of this disease is twice as likely than in European American (EA) women (2). In the AA population, there is also a higher incidence in premenopausal women with this disease $(3,4)$. Studies of Sub-Saharan and West African women indicate increased frequency and younger age of diagnoses of TNBC when compared to AA women (5). The five- and ten-year survival rates are lower for TNBC patients when compared to other breast cancer subtypes thus novel therapies are needed to increase survival especially in stage IV (6-8).

Over the years, several therapeutic targets have been purported in vitro and in vivo to be effective in TNBC treatment such as EGFR, PI3K/mTOR, PARP, Src and RAS/RAF/MEK inhibitors but in clinical trials many have failed to be efficacious $(9,10)$. Recently, a new class of drugs has been approved that target BRCA1/2-mutated TNBC patients. This class of drugs, PARP inhibitors, demonstrate synthetic lethality $(11,12)$. However, this class of drugs only targets approximately $15 \%$ of diagnosed TNBC (13). Topoisomerase I antibody drug conjugate, sacituzumab govitecan-hizy, has recently been approved for metastatic TNBC (14-16). In general, monotherapy for cancer treatment has been proven to be ineffective due to heterogeneity of cells within a tumor and development of drug resistance (17). Thus, novel compounds and innovative therapeutic combinations are needed for the treatment of breast cancer, particularly TNBC $(18,19)$. 
$\mathrm{Z} 285$ is a member of the 1,4 naphthoquinones class of compounds that have been shown to have anticancer, antibacterial, and antimalarial function (20-22). Similarly, Z285 has demonstrated cytotoxic effects in androgen-dependent and -independent prostate cancer cell lines as well as BC cell lines $(23,24) .4-\mathrm{OHT}$ is an active metabolite of tamoxifen, a drug routinely used as $\mathrm{BC}$ prophylaxis as well as treatment of ER $\alpha$ positive $\mathrm{BC}(25,26)$. Therefore, this study examines the use of 2,3-dichloro-5,8-dimethoxy-1,4-naphthoquinone (Z285) and 4-hydroxytamoxifen (4-OHT) alone or in combination as a novel therapeutic alternative for TNBC.

\section{Materials and Methods}

Materials. CellTiter $96^{\circledR}$ AQueous One Solution Cell Proliferation Assay was obtained from Promega (Madison, WI, USA) and DMSO was purchased from Sigma-Aldrich (St. Louis, MO, USA). 4hydroxytamoxifen was acquired from Fisher Scientific (Hanover Park, IL, USA) and PBS from Gibco (Gaithersburg, MD, USA). 2,3-Dichloro-5,8-dimethoxy-1,4-naphthoquinone was synthesized in house (23). CM-H2DCFDA was purchased from Invitrogen (Carlsbad, CA, USA). All drugs were made up as $10 \mathrm{mM}$ stock dissolved in DMSO.

Cell culture. Stock cultures of the human ER $\alpha$-positive BC (MCF7) and TNBC (HCC1806 obtained from AA patient and MDA-MB 231, Hs578T both taken from EA patients) cell lines were obtained from the American Type Culture Collection (ATCC) (Rockville, MD, USA). The cells were grown in $75 \mathrm{~cm}^{3}$ flasks in RPMI-1640 from ATCC (Rockville, MD, USA) medium supplemented with $10 \%$ fetal bovine serum (FBS) obtained from ATCC (Rockville, MD, USA) and $1 \%$ penicillin/streptomycin from Gibco (Gaithersburg, MD, USA) and incubated in humidified atmosphere $5 \% \mathrm{CO}_{2}$ at $37^{\circ} \mathrm{C}$. Upon reaching $80-90 \%$ confluency, the cells were trypsinized, and quantified with T10 cell counter from Bio-Rad (Hercules, CA, USA). For all experiments, cells were starved by plating in phenol free RPMI 1640, 1\% charcoal stripped FBS and 1\% penicillin/ streptomycin for $24 \mathrm{~h}$ to achieve cell cycle synchronization and limit estrogenic exposure. Drugs were diluted to appropriate concentrations in this media.

Cell proliferation. All cell lines were plated at $8 \times 10^{3}$ cells $/$ well in 96-well plate. Cells were allowed to attach overnight in growth media. The media was aspirated, and cells were further incubated in starvation media for $24 \mathrm{~h}$. Relevant concentrations of the compounds were diluted in starvation media.

Single drug: Cells were treated in a concentration- and timedependent manner with Z285 and 4-OHT at 0.1, 0.2, 0.5, 1, 2, 5, 10,20 and $50 \mu \mathrm{M}$ for 24,72 and $120 \mathrm{~h}$, respectively.

Combinatorial drug treatment: Cells were treated with $\mathrm{Z} 285$ for final concentrations of 2 or $5 \mu \mathrm{M}$ and $1,3,6,12,15 \mu \mathrm{M}$ of $4-\mathrm{OHT}$ for 24,72 and $120 \mathrm{~h}$.

At the end of the respective time periods, $20 \mu$ MTS was added to all the wells for $2 \mathrm{~h}$ and read at $495 \mathrm{~nm}$ using Perkin Elmer Wallac Victor 31420 plate reader (Waltham, MA, USA).

Data analysis: Graphpad v8 was used to calculate the $\mathrm{IC}_{50}$ for each cell line with each compound and its combination through nonlinear regression analysis.
Table I. IC 50 values of cells treated with Z285 alone at 24,72 and $120 \mathrm{~h}$.

\begin{tabular}{lccc}
\hline & \multicolumn{3}{c}{ Time } \\
\cline { 2 - 4 } Cell line & $24 \mathrm{~h}$ & $72 \mathrm{~h}$ & $120 \mathrm{~h}$ \\
\hline HCC1806 & $2.29 \times 10^{-5}$ & $4.26 \times 10^{-6}$ & $2.68 \times 10^{-6}$ \\
MDA-MB-231 & $1.35 \times 10^{-5}$ & $6.68 \times 10^{-6}$ & $3.28 \times 10^{-6}$ \\
Hs578T & $5.21 \times 10^{-6}$ & $5.92 \times 10^{-6}$ & $1.63 \times 10^{-6}$ \\
MCF7 & $1.20 \times 10^{-5}$ & $9.43 \times 10^{-6}$ & $5.50 \times 10^{-6}$ \\
\hline
\end{tabular}

Table II. IC 50 values of cells treated with 4-OHT alone at 24,72 and $120 \mathrm{~h}$.

\begin{tabular}{lccc}
\hline & \multicolumn{3}{c}{ Time } \\
\cline { 2 - 4 } Cell line & $24 \mathrm{~h}$ & $72 \mathrm{~h}$ & $120 \mathrm{~h}$ \\
\hline HCC1806 & $1.62 \times 10^{-5}$ & $8.58 \times 10^{-6}$ & $6.83 \times 10^{-6}$ \\
MDA-MB-231 & $1.48 \times 10^{-5}$ & $4.83 \times 10^{-6}$ & $2.65 \times 10^{-6}$ \\
Hs578T & $1.26 \times 10^{-5}$ & $8.07 \times 10^{-6}$ & $7.16 \times 10^{-6}$ \\
MCF7 & $1.99 \times 10^{-5}$ & $1.67 \times 10^{-5}$ & $8.47 \times 10^{-6}$ \\
\hline
\end{tabular}

Combinatorial synergy study. Cells were treated with Z285 with final concentrations of $1,2,4,8,16 \mu \mathrm{M}$ and with 4-OHT 3, 6, 12, $24,48 \mu \mathrm{M}$ for $72 \mathrm{~h}$. After $72 \mathrm{~h}, 20 \mu \mathrm{L}$ of MTS was added to the wells for 2 hours and read at $495 \mathrm{~nm}$ using Perkin Elmer Wallac Victor 31420 plate reader (Waltham, MA, USA).

Data analysis: Synergistic analysis was performed using Synergyfinder ${ }^{\circledR}$, utilizing the Bliss Independence Reference model.

ROS assay. According to the manufacturers guidelines (Invitrogen), media was aspirated, cells were then washed with room temperature PBS and incubated in $10 \mu \mathrm{M}$ CM-H2DCFA for $45 \mathrm{~min}$. The cells were additionally washed twice in PBS followed by treatment with Z285 at final concentrations of 2, 4, 8, and $16 \mu \mathrm{M}$ and at 4-OHT 3, 6, 12 and $24 \mu \mathrm{M}$ and their combination for $8 \mathrm{~h}$. Plate was read at $492-495 \mathrm{~nm}$ excitation and 517-527 nm emission using Biotek Cytation 3 imaging reader (Winooski, VT, USA).

Data analysis: One-way Anova followed by post-hoc Dunnetts test compared each mean to the control (untreated cells incubated with dye) was used to determine significance.

\section{Results}

In this study, three TNBC cell lines and one ER $\alpha$ expressing cell line were evaluated to determine the efficacy of Z285 and $4 \mathrm{OHT}$ alone and in combination on cell proliferation.

Z285 treatment. The cell line which was most susceptible to $\mathrm{Z} 285$ was Hs578T at 24 and $120 \mathrm{~h}$ with an $\mathrm{IC}_{50}$ of 5.21 and $1.63 \mu \mathrm{M}$, respectively. At $72 \mathrm{~h}$, HCC1806 showed the most sensitivity with an $\mathrm{IC}_{50}$ of $4.26 \mu \mathrm{M}$ as shown in Table I. MCF7 was least susceptible to Z285 at $72 \mathrm{~h}$ and $120 \mathrm{~h}$ with $\mathrm{IC}_{50}$ values of 9.43 and $5.50 \mu \mathrm{M}$, whereas HCC1806 showed the least sensitivity at $24 \mathrm{~h}$ with, respectively; $\mathrm{IC}_{50}$ of $22 \mu \mathrm{M}$ as shown in Figure 1A-C. 

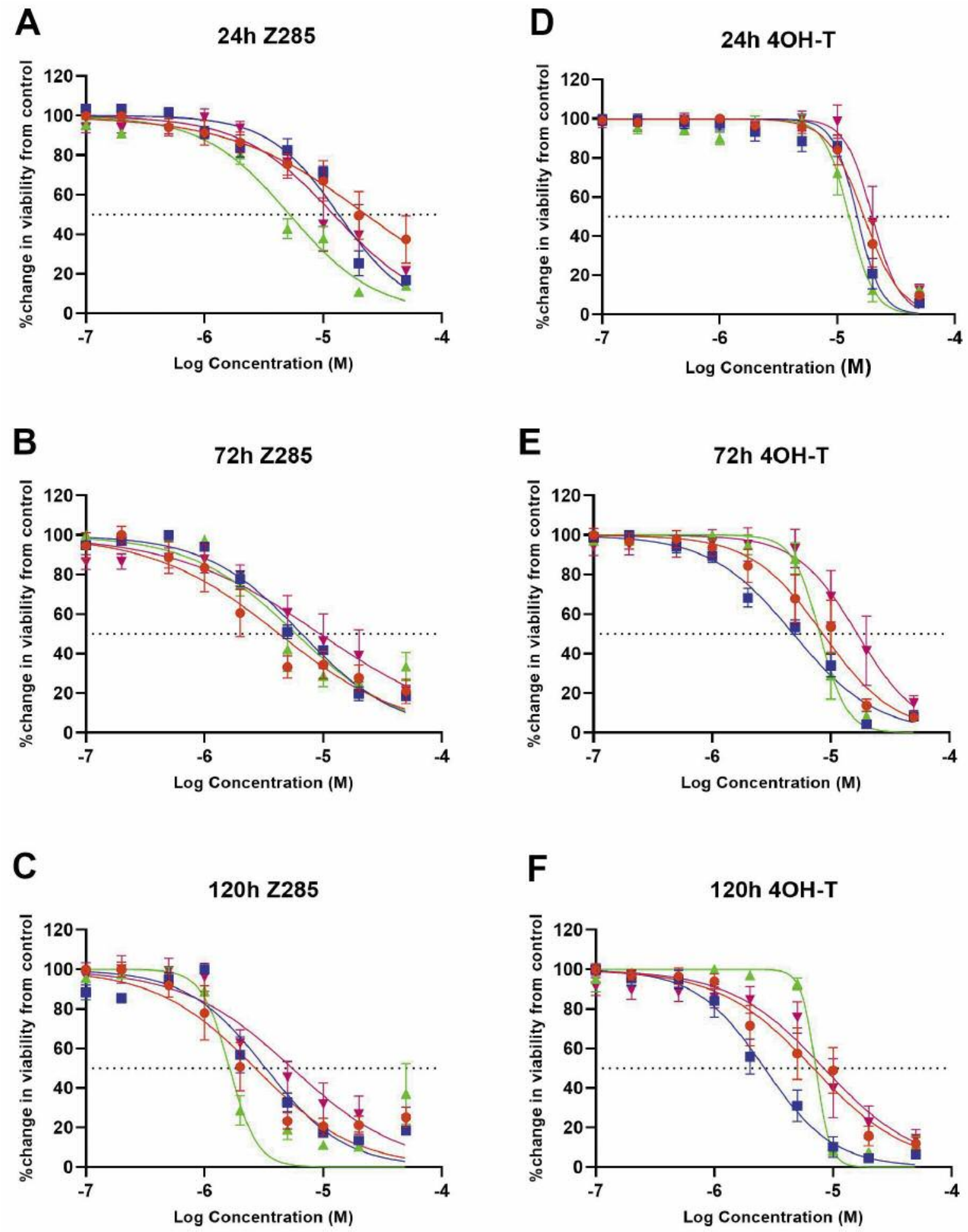

$\rightarrow \mathrm{HCC} 1806 \rightarrow \mathrm{MDA}-\mathrm{MB}-231 \rightarrow \mathrm{Hs} 578 \mathrm{~T} \rightarrow \mathrm{MCF} 7$

Figure 1. Cell viability assay of Z285 alone and 4-OHT alone treated cells at 24, 72 and $120 \mathrm{~h}$. (A) $24 \mathrm{~h} \mathrm{Z285,} \mathrm{(B)} 72 \mathrm{~h} \mathrm{Z285,(C)} 120 \mathrm{~h} Z 285$, (D) $24 \mathrm{~h}$ 4-OHT, (E) $72 \mathrm{~h}$ 4-OHT, (F) $120 \mathrm{~h}$ 4-OHT. After starving cells for $24 \mathrm{~h}, \mathrm{~A}-\mathrm{D}$ were treated with $0.1-50 \mu \mathrm{M}$ of Z285 and D-F were treated with 0.1-50 $\mu \mathrm{M}$ of 4-OHT. IC 50 was calculated by non-linear regression for each cell line at every time point. Each group analysis was performed in triplicate. 


\section{$24 \mathrm{~h}$}

A

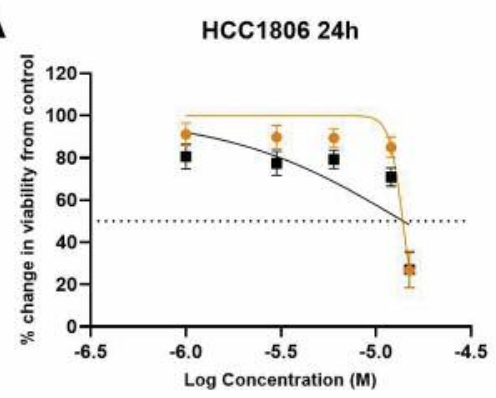

D

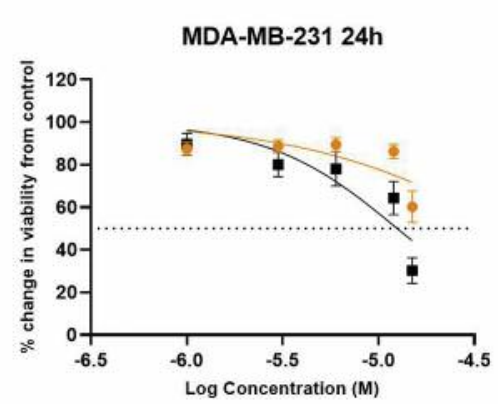

G

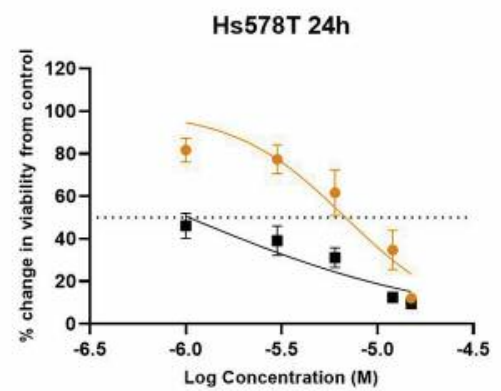

J

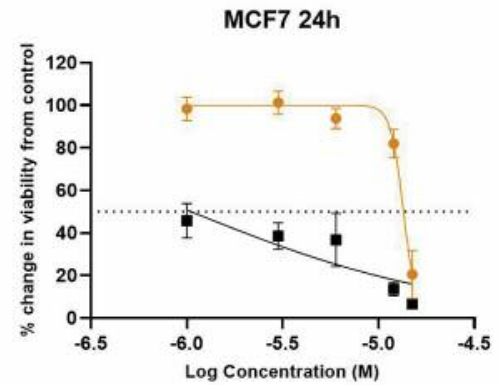

$72 \mathrm{~h}$

B

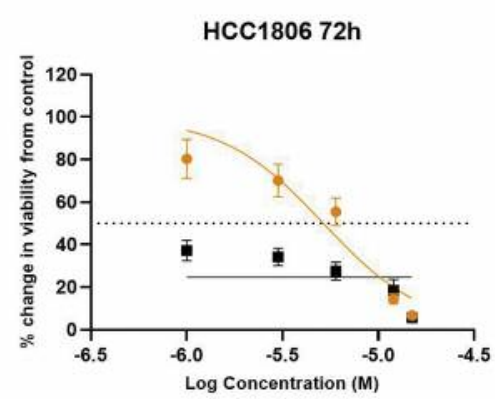

E

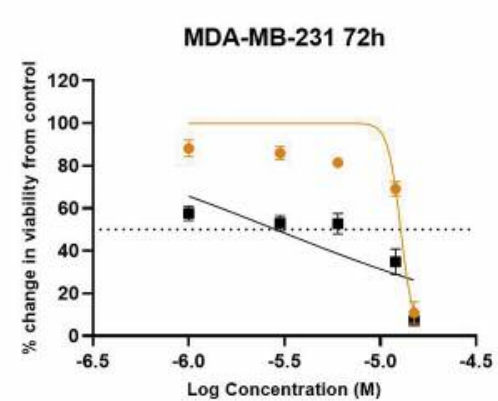

H

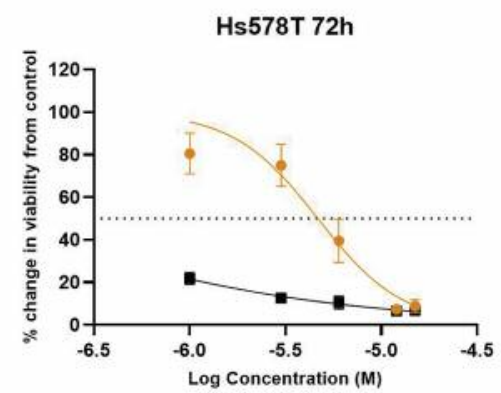

K

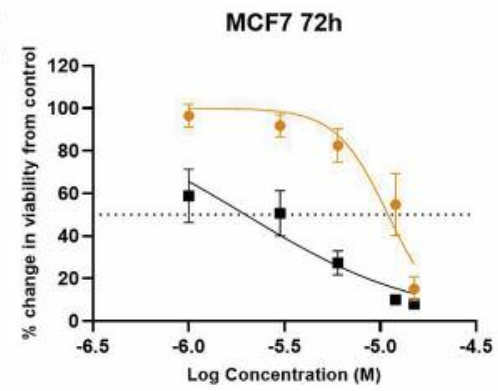

C

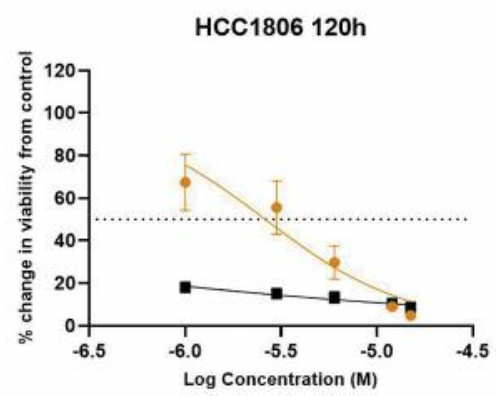

$\mathbf{F}$

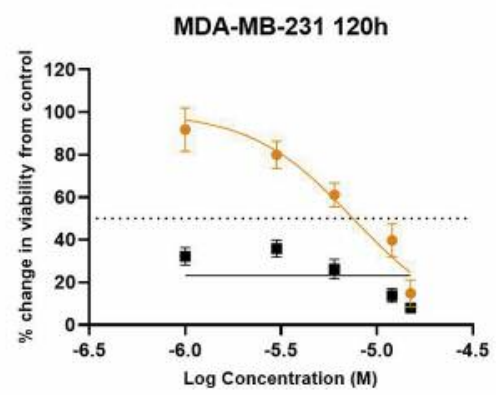

I

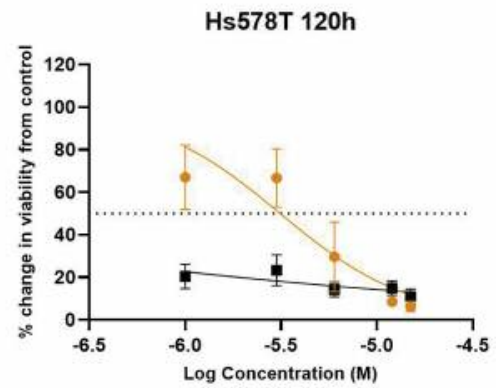

$\mathbf{L}$

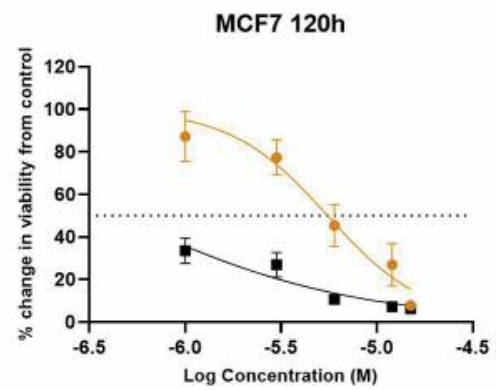

$\rightarrow 2 \mu \mathrm{M}$

$-5 \mu \mathrm{M}$

Figure 2. Cell viability assay of cells treated with Z285 and 4-OHT at 24, 72 and $120 \mathrm{~h}$. After starving cells for $24 \mathrm{~h}$. All cells were treated with either 2 or $5 \mu \mathrm{M}$ of Z285 and 1-15 $\mathrm{MM}$ of 4-OHT combined. Column 1 is 24 h, Column 2 is $72 \mathrm{~h}$ and column 3 is 120 h (A-C) are HCC1806, (DF) are MDA-MB-231, (G-I) are Hs578T and (J-L) are MCF7. Non-linear regression is perfored on every cell line at every time point. Each group analysis was performed in triplicate. 
4-OHT treatment. MDA-MB-231 exhibited the highest susceptibility at $14.8,4.83$ and $2.65 \mu \mathrm{M}$ for 24,72 and $120 \mathrm{~h}$, respectively as shown in Figure $1 \mathrm{D}-\mathrm{F}$. Whereas, the $\mathrm{IC}_{50}$ for HCC1806 decreased from 16.2 to $6.83 \mu \mathrm{M}$ and Hs578T showed a reduction in the $\mathrm{IC}_{50}$ from 12.6 to $7.16 \mu \mathrm{M}$ between $24 \mathrm{~h}$ and $120 \mathrm{~h}$. Interestingly, MCF7 was least sensitive to 4-OHT at every time point reaching an $\mathrm{IC}_{50}$ of approximately $20 \mu \mathrm{M}$ at $24 \mathrm{~h}$ and decreasing to $8.5 \mu \mathrm{M}$ by $120 \mathrm{~h}$ as shown in Table II.

Z285 and 4-OHT combination treatment. Each cell line demonstrated a reduction in cell proliferation following combination treatment. Z285 was given at 2 and $5 \mu \mathrm{M}$ in combination with 4-OHT at concentrations between 1 and $30 \mu \mathrm{M}$ (Figure 2). When compared to the $\mathrm{IC}_{50}$ of $4-\mathrm{OHT}$ alone, combination treatment with $\mathrm{Z} 285$ and 4-OHT showed decrease in the $\mathrm{IC}_{50}$ for HCC1806, Hs578T and MCF7 at concentrations of Z285 2 and $5 \mu \mathrm{M}$ and $5 \mu \mathrm{M} \mathrm{Z285}$ for MDA-MB-231 (Table III). HCC1806 showed a 14\% decrease in $\mathrm{IC}_{50}$ for at both concentrations of Z285 at $24 \mathrm{~h}$. A further $39 \%$ reduction was observed at $2 \mu \mathrm{M}$ of $\mathrm{Z} 285$ at $72 \mathrm{~h}$ and a 62 and $99 \%$ at $120 \mathrm{~h}$ was shown at 2 and $5 \mu \mathrm{M}$ Z285 when compared to 4-OHT-treated cells, respectively. MDA-MB-231 demonstrated a 15 and $41 \%$ decrease in $\mathrm{IC}_{50}$ at 24 and $72 \mathrm{~h}$ respectively after $5 \mu \mathrm{M}$ Z285 and 4-OHT combination when compared to 4-OHT alone. In Hs578T, the $\mathrm{IC}_{50}$ decreased by 48,42 and $56 \%$ for $2 \mu \mathrm{M}$ combination at 24,72 and $120 \mathrm{~h}$, respectively. Furthermore, a 92,98 and $99 \%$ decrease in $\mathrm{IC}_{50}$ was observed with $5 \mu \mathrm{M}$ combination at 24,72 and $120 \mathrm{~h}$, respectively. MCF7 showed approximately $33 \%$ decrease in $\mathrm{IC}_{50}$ for all time points in $2 \mu \mathrm{M}$ combination while at $5 \mu \mathrm{M}$ combination a $95 \%$ decrease in $\mathrm{IC}_{50}$ was seen at all times. It should be noted that the combination treatment at $2 \mu \mathrm{M}$ for MDAMB-231 showed an increase in the $\mathrm{IC}_{50}$ values when compared with 4-OHT by itself there was a 225, 165 and $188 \%$ increase in $\mathrm{IC}_{50}$ at 24,72 and $120 \mathrm{~h}$, respectively.

Combinatorial analysis. Analysis of drug combination by Synergyfinder ${ }^{\circledR}$ indicated Bliss $\delta$ scores of $0.9,4.9$, and 5.6 for $\mathrm{HCC} 1806, \mathrm{MCF} 7$ and Hs578T respectively, thereby showing an additive effect for decreased cell proliferation. MDA-MB-231 showed a score of -10 indicating an antagonistic effect (Figure 3). Bliss independence reference model in this software compares the observed versus predicted inhibition response and where less than -10 is considered antagonistic, between -10 and 10 is considered to be additive and above 10 is synergistic.

ROS generation. Z285 demonstrated a significant increase in oxidative stress in Hs78T, MCF7 and MDA-MB-231 at 8 and $16 \mu \mathrm{M}$ after $8 \mathrm{~h}$ exposure. Hs578T demonstrated the most significant increases in ROS with p-value $\leq 0.0001$ at both 8 and $16 \mu \mathrm{M}$ (Figure 4C). MDA-MB-231 and MCF7
Table III. Percentage change from 4-OHT treated cells alone.

\begin{tabular}{lrrrrrr}
\hline & \multicolumn{2}{c}{24} & \multicolumn{2}{c}{72} & \multicolumn{2}{c}{120} \\
\cline { 2 - 7 } & $2 \mu \mathrm{M}$ & $5 \mu \mathrm{M}$ & $2 \mu \mathrm{M}$ & $5 \mu \mathrm{M}$ & $2 \mu \mathrm{M}$ & $5 \mu \mathrm{M}$ \\
\hline HCC1806 & 14 & 14 & 39 & - & 61 & 99 \\
MDA-MB-231 & +225 & 15 & +165 & 41 & +188 & - \\
Hs578T & 48 & 92 & 42 & 98 & 56 & 99 \\
MCF7 & 33 & 95 & 34 & 88 & 35 & 95 \\
\hline
\end{tabular}

showed $p$-values of $\leq 0.01$ and $\leq 0.0001$ at 8 and $16 \mu \mathrm{M}$, shown respectively in Figure 4B and D. HCC1806 showed a trend increase in $\mathrm{ROS}$ levels without significance. HCC1806 treated with 4-OHT produced a significant increase in ROS levels at $24 \mu \mathrm{M}$ with a $p$-value of $\leq 0.05$. The other cell lines treated with 4-OHT showed no significant changes in ROS production (Figure 5A-D).

When Z285 and 4-OHT were combined, MDA-MB-231 and MCF7 showed some combinations with significant increases in ROS production. In comparison to the MDAMB-231 control, $16 \mu \mathrm{M}$ Z285 and $6 \mu \mathrm{M}$ 4-OHT combination caused an increase in ROS with a statistical significance of $p \leq 0.01$. MCF7 demonstrated significant increases in ROS levels at $4 \mu \mathrm{M} \mathrm{Z285}$ and $6 \mu \mathrm{M}, 8 \mu \mathrm{M} \mathrm{Z} 285$ and $3 \mu \mathrm{M} 4-$ OHT and $8 \mu \mathrm{M} \mathrm{Z285}$ and $6 \mu \mathrm{M} 4-\mathrm{OHT}$ with $p$-values of $\leq 0.05, \leq 0.01, \leq 0.05$, respectively. No statistical changes in ROS was observed in HCC1806 and MCF7 (Figure 6).

\section{Discussion}

TNBC loss of ER $\alpha, P R$ and HER2 receptors make it difficult to treat due to lack of receptor targets. Though treatment options for TNBC have improved in recent years with targeted therapy such as PARP and topoisomerase I, there is still a significant number of patients who are unresponsive to these drugs $(27,28)$. Data show a $73 \%$ five-survival rate of TNBC to a $96 \%$ five-survival rate for non-TNBC counterparts. This is based on the grade of tumor, stage of cancer, age of patient, and overall health status. Stage IV diagnoses of TNBC has a general survival rate as low as $26.7 \%(29,30)$.

This disease disproportionately effects premenopausal AA women, with twice as many AA women being diagnosed with this subtype when compared to EA women. Up to $40 \%$ of BC diagnoses in premenopausal AA women can be attributed to TNBC (31). In comparison to EA women, AA women demonstrate enhanced genetic risk factors like BRCA1, Aurora $\mathrm{A}$ and B, EZH2 and p53 mutations; as well as, increased rates of obesity and lower socioeconomic factors (32). TNBC in young women is more likely to be of a more aggressive subtype, and is more likely to present at an advanced stage, either because of its biological aggressive nature or because of 
A

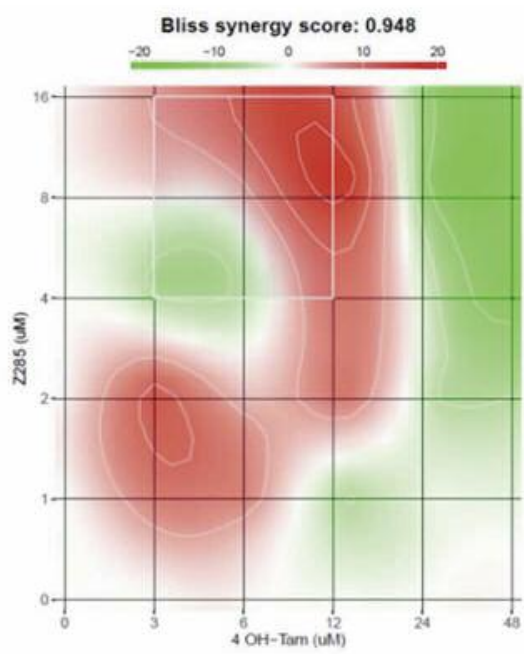

C

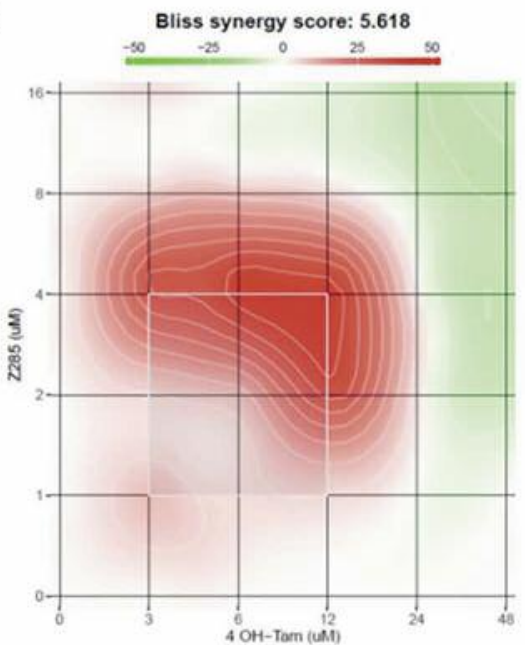

B

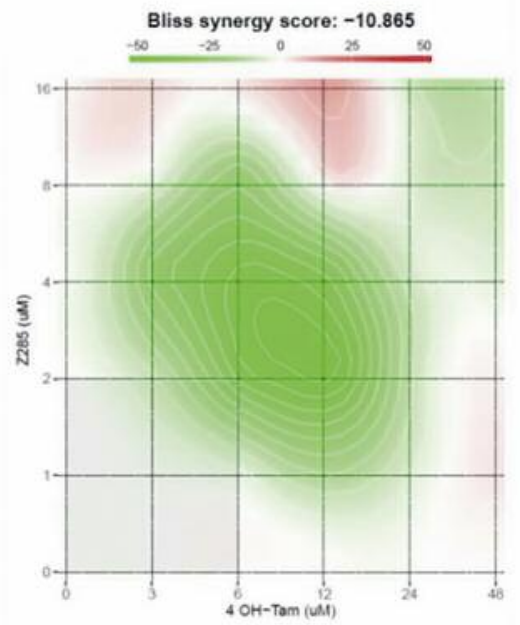

D

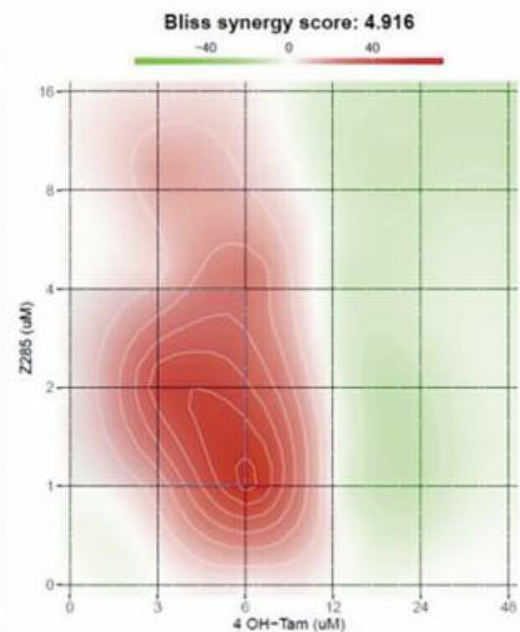

Figure 3. Combinatorial analysis of cell lines treated with Z285 and 4-OHT. (A) HCC1806, (B) MDA-MB-231, (C) Hs578T, (D) MCF7. Synergyfinder using Bliss Independence reference model determined that an additive effect was produced with $\delta$ scores of HCC1806, Hs578T and MCF7 and MDA-MB-231 treated cells resulted with an antagonsitic effect.

delayed diagnosis (33). Young age was seen as an independent prognostic factor. According to these findings, patients diagnosed with $\mathrm{BC}$ at $\leq 35$ years of age had a worse prognosis compared to premenopausal women above this age (34). Therefore, it is essential that innovative therapies are presented to increase the survivability of diagnosed patients.

This study investigated the efficacy of Z285 and 4-OHT as possible therapy for TNBC. Z285, is a 1,4 naphthoquinone with many therapeutic effects including antibacterial, antifungal, anti-inflammatory, antiviral and antitumor, specifically in prostate and breast cancer cell lines (35). In our previous study, it was shown that this compound causes inhibition of topoisomerase I, an enzyme responsible for producing single-strand breakage and relegation by unwinding supercoiled DNA to allow DNA replication and transcription. Thus inhibition of this enzyme can lead to apoptosis in BC cells $(24,36)$. Also, it significantly increases retinoblastoma, a tumor suppressor, levels in these cells. The cell proliferation inhibitory effects of Z285 has been previously observed in TNBC, ER $\alpha$ positive and androgen-dependent and independent prostate cancer cell lines. The compound was observed to cause cell-cycle arrest in the $\mathrm{S}$ phase in all BC cell lines as well as androgen-independent prostate cancer cell lines $(23,24)$. 

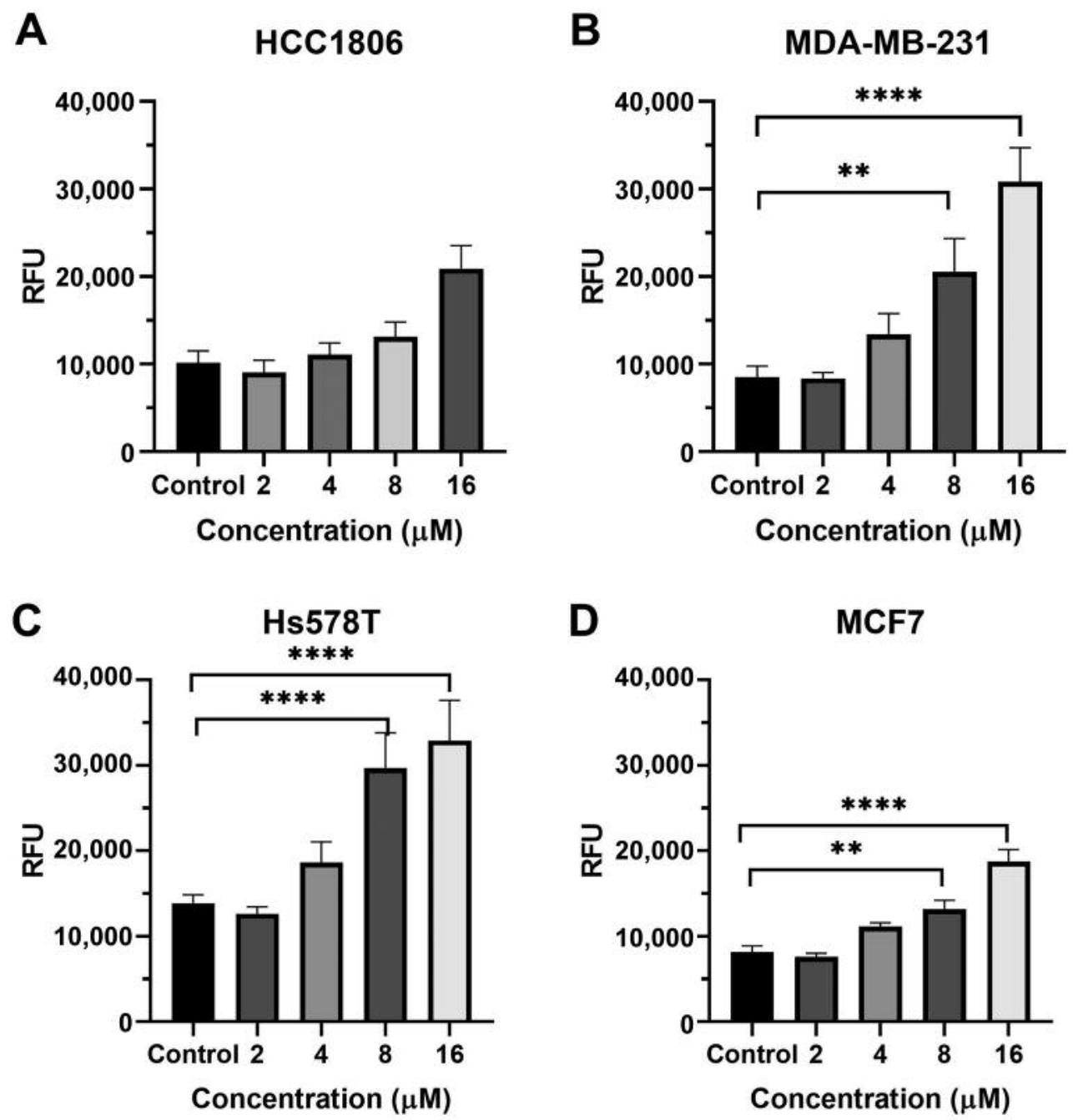

Figure 4. ROS assay of cells treated with Z285. (A) HCC1806, (B) MDA-MB-231, (C) Hs578T, (D) MCF7. Cells were washed with PBS after starving for 24h. A total of $10 \mu M C M-H 2 D C F A$ was added for 45 min, then the cells were washed with PBS twice before treatments were added. All cell lines were treated with Z285 at 2, 4, 8, and $16 \mu \mathrm{M}$ for $8 \mathrm{~h}$. One-way ANOVA followed by post-hoc Dunnetts test comparing each mean to the control (untreated cells with incubated with dye) was used to determine significance. Each group was performed in triplicate. $* * p \leq 0.01, * * * * p \leq 0.0001$.

In the present investigation, four $\mathrm{BC}$ cell lines were used including HCC1806, Hs578T, MDA-MB-231and MCF7. HCC1806 was used specifically to evaluate an AA TNBC cell line in comparison to EA cells. As described by Lehmann et al., TNBC can be subdivided into seven categories: basal-like 1 (BL1), basal-like (BL2), Mesenchymal (M), Mesenchymal stem-like (MSL), immunomodulatory (IM), luminal androgen receptor (LAR) and unstable (UNS) (9). BL1 and BL2 are described as basal-like with BL1 exhibiting greater DNA damage response and cell-cycle gene expression and BL2 is enriched in growth factor signaling and myoepithelial markers. Whereas LAR, expresses a 9-fold increase of AR expression compared to other subtypes and has luminal gene expression. M shows increased gene expression of epithelialmesenchymal-transition and growth factor pathways. MSL though similar to $M$ shows reduced expression of proliferative genes. IM has immune signaling transduction pathways most likely due to a mixture of tumor cells and infiltrating lymphocytes. UNS tumors do not fall into any of the aforementioned categories. Thus, HCC1806 is classified as BL2 and MDA-MB-231 and Hs578T are categorized as MSL (9).

The evaluation did corroborate prior results as well as demonstrate the compounds ability to decrease cell proliferation in the multiple TNBC cell lines. Prior data indicate topoisomerase I inhibition as a mechanism for 
A

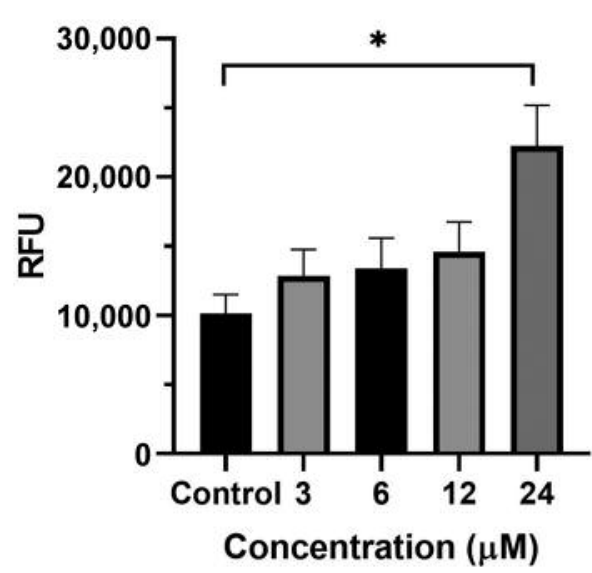

c

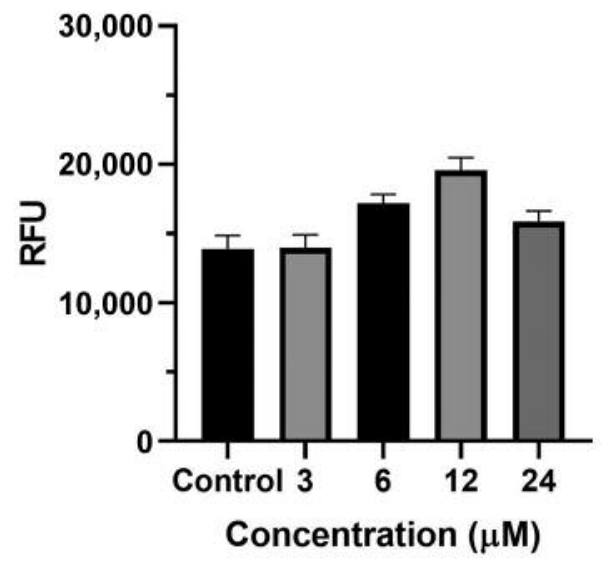

B

MDA-MB-231

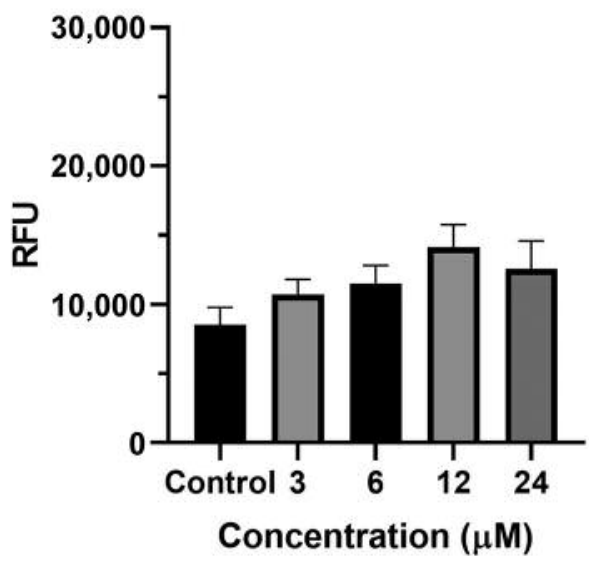

MCF7

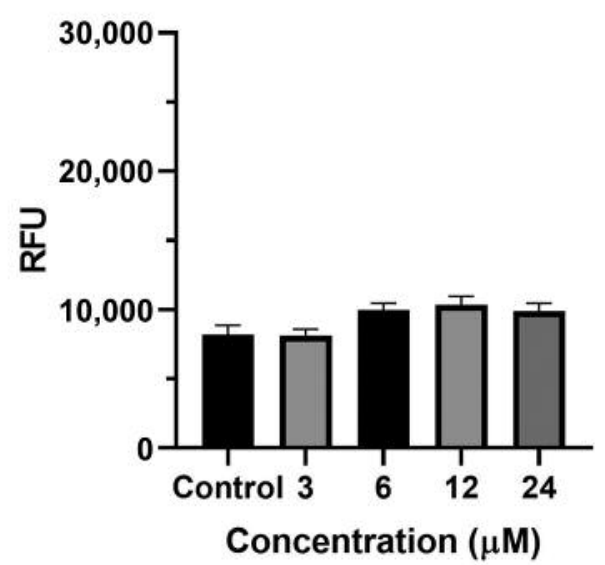

Figure 5. ROS assay of cells treated with 4-OHT. (A) HCC1806, (B) MDA-MB-231, (C) Hs578T, (D) MCF7. Cells were washed with PBS after starving for $24 \mathrm{~h}$. A total of $10 \mu \mathrm{M} C \mathrm{CM}$-H2DCFA was added for $45 \mathrm{~min}$, then the cells were washed with PBS twice before treatments were added. A-D were treated with 3, 6, 12 and $24 \mu M$ for 8 h. One-way ANOVA followed by post-hoc Dunnetts test comparing each mean to the control (untreated cells with incubated with dye) was used to determine significance. Each group analysis was performed in triplicate, ${ }^{*} p \leq 0.05$.

inhibition of cell viability, it is important to note that other mechanisms can be suggested for this compound's action especially as the androgen dependent cells were not arrested in the S-phase similar to the other cell lines. Further, topoisomerase II is responsible for recombination, the separation of daughter chromosomes, and proper chromosome structure, condensation, and decondensation and inhibition of this enzyme is associated with other compounds in this class (37).

It may be suggested that BC cells treated with Z285 in the current study causes an increased generation of ROS resulting in alterations in cell signaling leading to cell damage thereby causing decreased cell proliferation. This cellular damage could be caused by hydroxyl radicals binding to cysteine-rich proteins and lipids, resulting in lipid peroxidation of cellular membrane and leading to apoptosis (38-42).

Concentration-response of the cell lines with 4-OHT produced interesting results with MCF7 in that they were the least sensitive to the drug as compared to the TNBC cell lines. These cell lines do not express the ER $\alpha$ target commonly associated with this drug so they should not be more susceptible to 4-OHT. Studies by Lin et al., (39) and Yaacob and Ismail (40) corroborated the MCF data from the current study in that high concentrations above $10 \mu \mathrm{M}$ of 4 OHT failed to produce a $50 \%$ reduction in cell proliferation in MCF7 cells. 
A

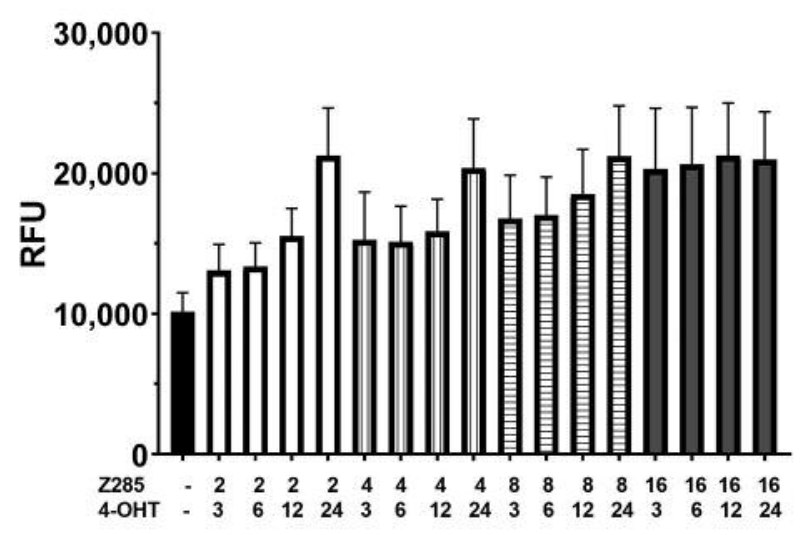

Concentration $(\mu \mathrm{M})$

B

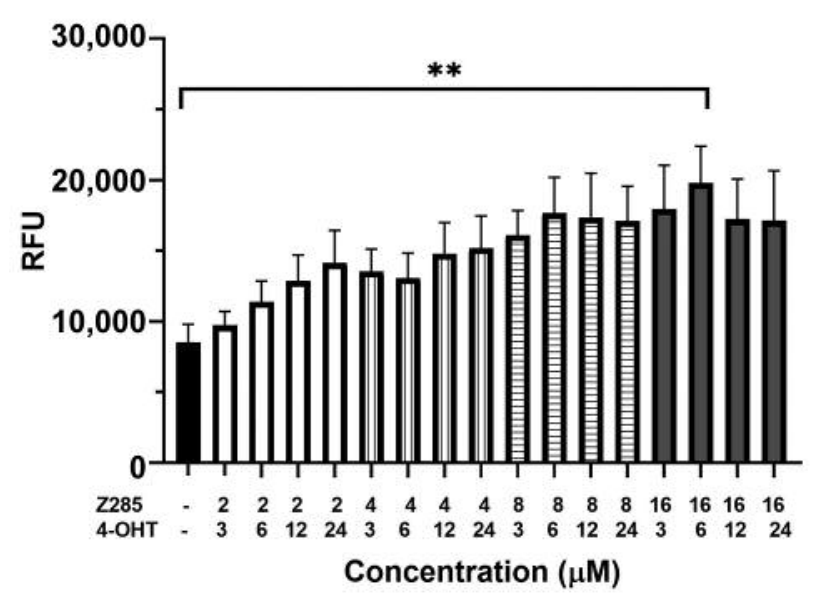

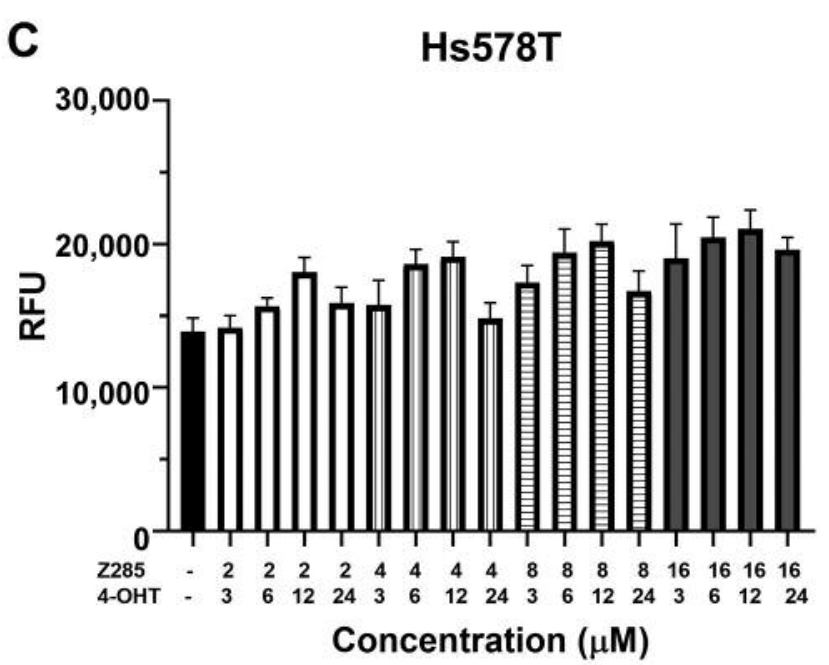

D

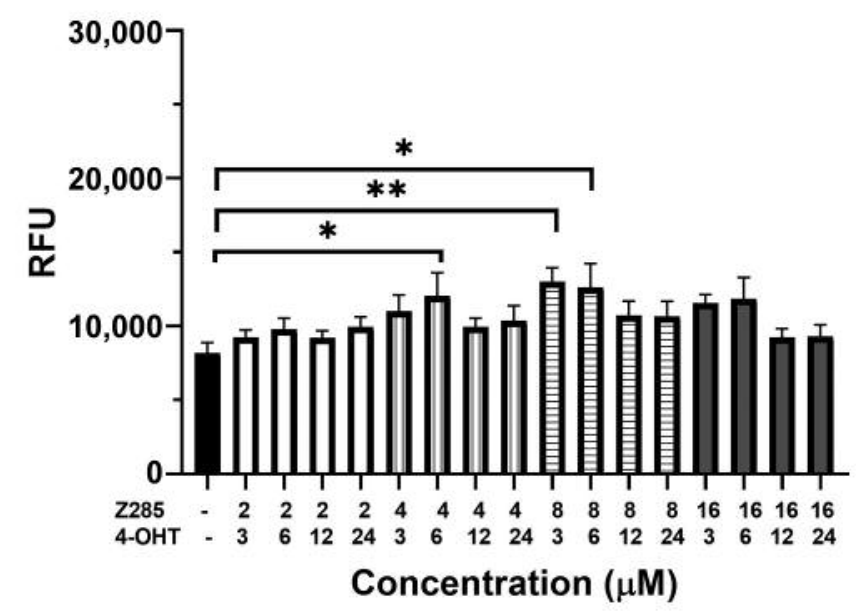

Figure 6. ROS assay of combination treatment with Z285 and 4-OHT. (A) HCC1806, (B) MDA-MB-231, (C) Hs578T, (D) MCF7. Cells were washed with PBS after starving for $24 \mathrm{~h} .10 \mu \mathrm{M} C M-H 2 D C F A$ was added for $45 \mathrm{~min}$, then the cells were washed with PBS twice before treatments were added. A-D were treated with a combintion of Z285 at 2, 4, 8, and $16 \mu \mathrm{M}$ and 3, 6, 12 and $24 \mu \mathrm{M}$ for 8 h. One-way ANOVA followed by post-hoc Dunnetts test comparing each mean to the control (untreated cells with incubated with dye) was used to determine significance. Each group was performed in triplicate. $* p \leq 0.05, * * \leq 0.01$.

Tamoxifen and its active metabolites, endoxifen and 4OHT are ligands for ER $\alpha$; as well as, ER $\beta$, GPER1, Estrogen Related Receptor $\beta$ and Estrogen Related Receptor $\gamma$ (43-45). 4-OHT has a similar relative binding affinities (RBA) to both $\mathrm{ER} \alpha$ and $\operatorname{Er} \beta$ (46) when compared to tamoxifen. On its own, 4-OHT decreased proliferation in MCF7 as expected but it also decreased proliferation in all three TNBC cell lines with greater sensitivity. Studies by Manna and Holz showed that 5-10\% of ER $\alpha$-negative cells are susceptible to tamoxifen (47). This can be attributed to the varying levels of expression of ER $\beta$ in these cell lines (48-51). 4-OHT is an agonist for ER $\beta$ inhibiting cell proliferation, migration, and invasion in TNBC cell lines (52). ERs have ER/ ligand independent activity that can lead to activation of cytoplasmic proteins or phosphorylation of transcription factors (53).

Synergyfinder ${ }^{\circledR}$ using Bliss independence reference model was used to identify the relationship between the two compounds when combined (54). The effects of the drug combination showed an additive relationship in decreasing cell proliferation in HCC1806, Hs578T and MCF7. The additive relationship demonstrated in these cell lines maybe due to the changes in ROS production or DNA damage caused by Z285 thus increasing the susceptibility of the cells to 4-OHT. 
Though this combination demonstrates additivity in most of these cell lines, the methods of cell death may vary.

MDA-MB-231 demonstrated an antagonistic response with the compound combination. Lin et al., also observed some antagonistic responses when treating this cell line with shikonin and 4-OHT, shikonin being a naphthoquinone (55). This response may indicate a functional independence of the two compounds on cell proliferation. MDA-MB-231 cells have hypermethylation of $\mathrm{CpG}$ island in the promoter region of ESRl thus effectively silencing the gene (56). Moreover, it has been proposed that the loss of ER $\alpha$ expression is due to the hyperactivation of MAPK $(57,58)$. Therefore, ROS production may modulate MAPK thus altering ER $\alpha$ expression in the other cell lines, but this would be ineffective in MDA-MB-231 (59).

CM-H2DCFDA indirectly reacts with $\mathrm{H}_{2} \mathrm{O}_{2}$ to produce a fluorescent molecule that is used to measure ROS levels (60). The increase in oxidative stress after $8 \mathrm{~h}$ corresponds to the decrease in cell proliferation seen at $24 \mathrm{~h}$ with HCC1806 being the least responsive and Hs578T showing increased susceptibility to Z285. It has been shown that 1,4 naphthoquinone derivatives can increase ROS levels and modulate the three major MAPK pathways ERK, JNK and p38 as well as the PI3K/AKT and JAK/STAT3 (61-64). These cellular stressors can cause a reduction in cell proliferation and an induction of apoptosis. In the current study, treatment with 4-OHT produced an increased trend in ROS production, whereas, at high concentration there was a slight decrease in ROS levels in MDA-MB-231 and Hs578T. Bekele et al., reported that incubation of MCF7 at 24h shows a significant increase in ROS (65). Therefore, a longer incubation period maybe required to achieve statistically significant increases in ROS production in the other cell lines. The combination treatment of the two compounds demonstrated an increase trend in the ROS production in HCC1806 and Hs578T.

The additive effect observed in the synergy analysis maybe due to other mechanisms independent of increased ROS generation. Kawiak et al., suggested that glucose regulated protein 78 (GRP78) down-regulation and Bcl-2interacting killer (Bik) up-regulation by plumbagin was shown to increase the sensitivity of MCF7 and T47D to tamoxifen. Bik is a proapoptotic protein and increased Bik forms a complex with $\mathrm{Bcl}-2$ on the endoplasmic reticulum activating apoptotic process (66). In addition, the activation of c-jun by JNK signaling is needed for 4-OHT induced cell death and 1,4 napthoquinones have demonstrated an increase in JNK activation and thus potentially enhancing the effect when the compounds are combined $(67,68)$.

Future studies with an expanded number of AA TNBC cell lines would be needed to improve comparison between the two ethnicities. Also, expansion into increased molecular subtypes of TNBC cell lines (i.e. LAR and BL1) would further the knowledge of the efficacy of Z285 and 4OH-T combination for all TNBC. This information may be translated into a molecular subytpe-specific therapeutic modality for TNBC.

\section{Conclusion}

The present study demonstrated a beneficial relationship between Z285 and 4-OHT. However, the mechanisms that are associated with the additive effect have not been fully elucidated. Therefore, combination of these two compounds may be an alternative therapy for TNBC patients who are unresponsive to other treatments.

\section{Conflicts of Interest}

The Authors have no conflicts of interest to declare.

\section{Authors' Contributions}

Experimental design was performed by AGJR and RLC. Experiments and statistical analysis were performed by AGJR. AGJR, YMK and RLC were responsible for manuscript writing and editing.

\section{Acknowledgements}

This work was supported by funding from the Charles and Mary Latham Foundation Fund. The Authors would like to thank Dr. O. Bakare from the Department of Chemistry at Howard University for generously providing Z285.

\section{References}

1 Singh J, Asad S, Zhang Y, Nock W, Adams E, Damicis A, Ramaswamy B, Williams N, Parsons HA, Adalsteinsson VA, Winer EP, Lin NU, Partridge AH, Overmoyer B and Stover DG: Aggressive subsets of metastatic triple negative breast cancer. Clin Breast Cancer 20: e20-e26, 2020. PMID: 31631016. DOI: 10.1016/j.clbc.2019.06.012

2 Purrington KS, Knight J, Dyson G, Ali-Fehmi R, Schwartz AG, Boerner JL and Bandyopadhyay S: CLCA2 expression is associated with survival among African American women with triple negative breast cancer. PLoS One 15: e0231712, 2020. PMID: 32298355. DOI: 10.1371/journal.pone.0231712

3 Ma H, Ursin G, Xu X, Lee E, Togawa K, Duan L, Lu Y, Malone KE, Marchbanks PA, McDonald JA, Simon MS, Folger SG, Sullivan-Halley J, Deapen DM, Press MF and Bernstein L: Reproductive factors and the risk of triple-negative breast cancer in white women and African-American women: a pooled analysis. Breast Cancer Res 19: 6, 2017. PMID: 28086982. DOI: 10.1186/s13058-016-0799-9

4 Dolle JM, Daling JR, White E, Brinton LA, Doody DR, Porter $\mathrm{PL}$ and Malone KE: Risk factors for triple-negative breast cancer in women under the age of 45 years. Cancer Epidemiol Biomarkers Prev 18: 1157-1166, 2009. PMID: 19336554. DOI: 10.1158/1055-9965.EPI-08-1005

5 Dietze EC, Sistrunk C, Miranda-Carboni G, O'Regan R and Seewaldt VL: Triple-negative breast cancer in African-American 
women: disparities versus biology. Nat Rev Cancer 15: 248-254, 2015. PMID: 25673085. DOI: 10.1038/nrc3896

6 Reddy SM, Barcenas CH, Sinha AK, Hsu L, Moulder SL, Tripathy D, Hortobagyi GN and Valero V: Long-term survival outcomes of triple-receptor negative breast cancer survivors who are disease free at 5 years and relationship with low hormone receptor positivity. Br J Cancer 118: 17-23, 2018. PMID: 29235566. DOI: $10.1038 /$ bjc.2017.379

7 James M, Dixit A, Robinson B, Frampton C and Davey V: Outcomes for Patients with Non-metastatic Triple-negative breast cancer in New Zealand. Clin Oncol (R Coll Radiol) 31: 17-24, 2019. PMID: 30274766. DOI: 10.1016/j.clon.2018.09.006

8 Doepker MP, Holt SD, Durkin MW, Chu CH and Nottingham JM: Triple-negative breast cancer: A comparison of race and survival. Am Surg 84: 881-888, 2018. PMID: 29981619. DOI: $10.1177 / 000313481808400636$

9 Lehmann BDB, Bauer J a J, Chen X, Sanders ME, Chakravarthy a B, Shyr Y and Pietenpol J a: Identification of human triplenegative breast cancer subtypes and preclinical models for selection of targeted therapies. J Clin Invest 121: 2750-2767, 2011. PMID: 21633166. DOI: 10.1172/JCI45014DS1

10 Uscanga-Perales GI, Santuario-Facio SK and Ortiz-López R: Triple negative breast cancer: Deciphering the biology and heterogeneity. Med Univ 18: 105-114, 2016. DOI: 10.1016/ j.rmu.2016.05.007

11 Yadav BS, Sharma SC, Chanana P and Jhamb S: Systemic treatment strategies for triple-negative breast cancer. World J Clin Oncol 5: 125-133, 2014. PMID: 24829859. DOI: 10.5306/wjco.v5.i2.125

12 Anders CK, Winer EP, Ford JM, Dent R, Silver DP, Sledge GW and Carey LA: Poly(ADP-ribose) polymerase inhibition: "Targeted" therapy for triple-negative breast cancer. Clin Cancer Res 16: 4702-4710, 2010. PMID: 20858840. DOI: 10.1158/ 1078-0432.CCR-10-0939

13 Ellsworth DL, Turner CE and Ellsworth RE: A review of the hereditary component of triple negative breast cancer: High- and moderate-penetrance breast cancer genes, low-penetrance loci, and the role of nontraditional genetic elements. J Oncol 2019: 4382606, 2019. PMID: 31379942. DOI: 10.1155/2019/4382606

14 Cyprian FS, Akhtar S, Gatalica Z and Vranic S: Targeted immunotherapy with a checkpoint inhibitor in combination with chemotherapy: A new clinical paradigm in the treatment of triple-negative breast cancer. Bosn J Basic Med Sci 19: 227-233, 2019. PMID: 30915922. DOI: 10.17305/bjbms.2019.4204

15 Marra A, Viale G and Curigliano G: Recent advances in triple negative breast cancer: the immunotherapy era. BMC Med 17: 90, 2019. PMID: 31068190. DOI: 10.1186/s12916-019-1326-5

16 Bardia A, Mayer IA, Vahdat LT, Tolaney SM, Isakoff SJ, Diamond JR, O'Shaughnessy J, Moroose RL, Santin AD, Abramson VG, Shah NC, Rugo HS, Goldenberg DM, Sweidan AM, Iannone R, Washkowitz S, Sharkey RM, Wegener WA and Kalinsky K: Sacituzumab govitecan-hziy in refractory metastatic triple-negative breast cancer. N Engl J Med 380: 741-751, 2019. PMID: 30786188. DOI: 10.1056/NEJMoa1814213

17 Palmer AC and Sorger PK: Combination cancer therapy can confer benefit via patient-to-patient variability without drug additivity or synergy. Cell 171: 1678-1691.e13, 2017. PMID: 29245013. DOI: 10.1016/j.cell.2017.11.009

18 Isakoff SJ: Triple Negative Breast Cancer: Role of specific chemotherapy agents. cancer J 16: 53-61, 2010. PMID: 20164691. DOI: 10.1097/PPO.0b013e3181d24ff7.Triple
19 Bayat Mokhtari R, Homayouni TS, Baluch N, Morgatskaya E, Kumar S, Das B and Yeger H: Combination therapy in combating cancer. Oncotarget 8: 38022-38043, 2017. PMID: 28410237. DOI: $10.18632 /$ oncotarget.16723

20 Ravichandiran P, Sheet S, Premnath D, Kim AR and Yoo DJ: 1,4-naphthoquinone analogues: Potent antibacterial agents and mode of action evaluation. Molecules 24: 1437, 2019. PMID: 30979056. DOI: 10.3390/molecules24071437

21 Verma R: Anti-cancer activities of 1,4-naphthoquinones: A QSAR study. Anticancer Agents Med Chem 6: 489-499, 2006. PMID: 17017857. DOI: $10.2174 / 187152006778226512$

22 Belorgey D, Lanfranchi DA and Davioud-Charvet E: 1,4naphthoquinones and other NADPH-dependent glutathione reductase-catalyzed redox cyclers as antimalarial agents. Curr Pharm Des 19: 2512-28, 2013. PMID: 23116403. DOI: 10.2174/1381612811319140003

23 Copeland RL, Das JR, Bakare O, Enwerem NM, Berhe S, Hillaire K, White D, Beyene D, Kassim OO and Kanaan YM: Cytotoxicity of 2,3-dichloro-5,8-dimethoxy-1,4-naphthoquinone in androgen-dependent and -independent prostate cancer cell lines. Anticancer Res 27: 1537-1546, 2007. PMID: 17595773.

24 Kanaan YM, Das JR, Bakare O, Enwerem NM, Berhe S, Beyene D, Williams V, Zhou Y and Copeland RL: Biological evaluation of 2,3-dichloro-5,8-dimethoxy-1,4-naphthoquinone as an antibreast cancer agent. Anticancer Res 29: 191-199, 2009. PMID: 19331150.

25 Nazarali SA and Narod SA: Tamoxifen for women at high risk of breast cancer. Breast Cancer (Dove Med Press) 6: 29-36, 2014. PMID: 24648767. DOI: 10.2147/BCTT.S43763

26 Cuzick J, Forbes JF, Sestak I, Cawthorn S, Hamed H, Holli K, Howell A and International Breast Cancer Intervention Study I Investigators: Long-term results of tamoxifen prophylaxis for breast cancer-96-month follow-up of the randomized IBIS-I trial. J Natl Cancer Inst 99: 272-282, 2007. PMID: 17312304. DOI: $10.1093 /$ jnci/djk049

27 Shao B, Li C-W, Lim S-O, Sun L, Lai Y-J, Hou J, Liu C, Chang C-W, Qiu Y, Hsu J-M, Chan L-C, Zha Z, Li H and Hung M-C: Deglycosylation of PD-L1 by 2-deoxyglucose reverses PARP inhibitor-induced immunosuppression in triple-negative breast cancer. Am J Cancer Res 8: 1837-1846, 2018. PMID: 30323975.

28 D'Andrea AD: Mechanisms of PARP inhibitor sensitivity and resistance. DNA Repair (Amst) 71: 172-176, 2018. PMID: 30177437. DOI: 10.1016/j.dnarep.2018.08.021

29 Urru SAM, Gallus S, Bosetti C, Moi T, Medda R, Sollai E, Murgia A, Sanges F, Pira G, Manca A, Palmas D, Floris M, Asunis AM, Atzori F, Carru C, D'Incalci M, Ghiani M, Marras V, Onnis D, Santona MC, Sarobba G, Valle E, Canu L, Cossu S, Bulfone A, Rocca PC, De Miglio MR and Orrù S: Clinical and pathological factors influencing survival in a large cohort of triple-negative breast cancer patients. BMC Cancer 18: 56, 2018. PMID: 29310602. DOI: 10.1186/s12885-017-3969-y

30 Podo F, Santoro F, Di Leo G, Manoukian S, de Giacomi C, Corcione S, Cortesi L, Carbonaro LA, Trimboli RM, Cilotti A, Preda L, Bonanni B, Pensabene M, Martincich L, Savarese A, Contegiacomo A and Sardanelli F: Triple-negative versus nontriple-negative breast cancers in high-risk women: Phenotype features and survival from the HIBCRIT-1 MRI-including screening study. Clin Cancer Res 22: 895-904, 2016. PMID: 26503945. DOI: 10.1158/1078-0432.CCR-15-0459 
31 Lindner R, Sullivan C, Offor O, Lezon-Geyda K, Halligan K, Fischbach N, Shah M, Bossuyt V, Schulz V, Tuck DP and Harris LN: Molecular phenotypes in triple negative breast cancer from African American patients suggest targets for therapy. PLoS One 8: e71915, 2013. PMID: 24260093. DOI: 10.1371/journal. pone.0071915

32 Siddharth S and Sharma D: Racial disparity and triple-negative breast cancer in African-American women: A multifaceted affair between obesity, biology, and socioeconomic determinants. Cancers (Basel) 10: 514, 2018. PMID: 30558195. DOI: 10.3390/cancers10120514

33 Dubsky PC, Gnant MFX, Taucher S, Roka S, Kandioler D, Pichler-Gebhard B, Agstner I, Seifert M, Sevelda P and Jakesz R: Young age as an independent adverse prognostic factor in premenopausal patients with breast cancer. Clin Breast Cancer 3: 65-72, 2002. PMID: 12020397. DOI: 10.3816/CBC.2002.n.013

34 Owrang M, Copeland RL, Ricks-Santi LJ, Gaskins M, Beyene D, Dewitty RL and Kanaan YM: Breast cancer prognosis for young patients. In Vivo 31: 661-668. PMID: 28652435. DOI: 10.21873/invivo.11109

35 Kanaan YM, White DF, Das JR, Berhe S, Bakare O, Kenguele H, Beyene D, Zhou Y, Day AA and Copeland RL: Cytotoxic effects of N-(3-chloro-1,4-dioxo 1,4-dihydro-naphthalen-2-yl)benzamide on androgen-dependent and -independent prostate cancer cell lines. Anticancer Res 30: 519-527, 2010. PMID: 20332464

$36 \mathrm{Li} \mathrm{M}$ and Liu Y: Topoisomerase I in human disease pathogenesis and treatments. genomics proteomics bioinformatics 14: 166171, 2016. PMID: 27181710. DOI: 10.1016/j.gpb.2016.02.004

$37 \mathrm{McClendon}$ AK and Osheroff N: DNA topoisomerase II, genotoxicity, and cancer. Mutat Res 623: 83-97, 2007. PMID: 17681352. DOI: 10.1016/j.mrfmmm.2007.06.009

38 Klaus V, Hartmann T, Gambini J, Graf P, Stahl W, Hartwig A and Klotz L-O: 1,4-Naphthoquinones as inducers of oxidative damage and stress signaling in $\mathrm{HaCaT}$ human keratinocytes. Arch Biochem Biophys 496: 93-100, 2010. PMID: 20153715. DOI: $10.1016 /$ j.abb.2010.02.002

39 Coelho-Cerqueira E, Netz PA, do Canto VP, Pinto AC and Follmer C: Beyond topoisomerase inhibition: antitumor 1,4naphthoquinones as potential inhibitors of human monoamine oxidase. Chem Biol Drug Des 83: 401-410, 2014. PMID: 24165164. DOI: $10.1111 /$ cbdd.12255

40 Widhalm JR and Rhodes D: Biosynthesis and molecular actions of specialized 1,4-naphthoquinone natural products produced by horticultural plants. Hortic Res 3: 16046, 2016. PMID: 27688 890. DOI: 10.1038 /hortres.2016.46

41 Barrera G: Oxidative stress and lipid peroxidation products in cancer progression and therapy. ISRN Oncol 2012: 137289, 2012. PMID: 23119185. DOI: $10.5402 / 2012 / 137289$

42 Schieber $M$ and Chandel NS: ROS function in redox signaling and oxidative stress. Curr Biol 24: R453-462, 2014. PMID: 24845678. DOI: 10.1016/j.cub.2014.03.034

43 Li Y, Chen Y, Zhu Z-X, Liu X-H, Yang L, Wan L, Lei T-W and Wang X-D: 4-Hydroxytamoxifen-stimulated processing of cyclin $\mathrm{E}$ is mediated via $\mathrm{G}$ protein-coupled receptor 30 (GPR30) and accompanied by enhanced migration in MCF-7 breast cancer cells. Toxicology 309: 61-65, 2013. PMID: 23624423. DOI: 10.1016/j.tox.2013.04.012

44 Tremblay GB, Bergeron D and Giguere V: 4-Hydroxytamoxifen is an isoform-specific inhibitor of orphan estrogen-receptor-related
(ERR) nuclear receptors beta and gamma. Endocrinology 142: 4572-4575, 2001. PMID: 11564725. DOI: 10.1210/endo.142. 10.8528

45 Coward P, Lee D, Hull MV and Lehmann JM: 4Hydroxytamoxifen binds to and deactivates the estrogen-related receptor gamma. Proc Natl Acad Sci USA 98: 8880-8884, 2001. PMID: 11447273. DOI: 10.1073/pnas.151244398

46 Weatherman R V, Clegg NJ and Scanlan TS: Differential SERM activation of the estrogen receptors (ERalpha and ERbeta) at AP1 sites. Chem Biol 8: 427-436, 2001. PMID: 11358690. DOI: 10.1016/s1074-5521(01)00025-4

47 Manna S and Holz MK: Tamoxifen action in ER-negative breast cancer. Sign Transduct Insights 5: 1-7, 2016. PMID: 26989346. DOI: $10.4137 /$ STI.S29901

48 Al-Bader M, Ford C, Al-Ayadhy B and Francis I: Analysis of estrogen receptor isoforms and variants in breast cancer cell lines. Exp Ther Med 2: 537-544, 2011. PMID: 22977537. DOI: 10.3892/etm.2011.226

49 Hinsche O, Girgert R, Emons G and Gründker C: Estrogen receptor $\beta$ selective agonists reduce invasiveness of triplenegative breast cancer cells. Int J Oncol 46: 878-884, 2015. PMID: 25420519. DOI: 10.3892/ijo.2014.2778

50 Schüler-Toprak S, Häring J, Inwald EC, Moehle C, Ortmann O and Treeck O: Agonists and knockdown of estrogen receptor $\beta$ differentially affect invasion of triple-negative breast cancer cells in vitro. BMC Cancer 16: 951, 2016. PMID: 28003019. DOI: 10.1186/s12885-016-2973-y

51 Rizza P, Barone I, Zito D, Giordano F, Lanzino M, De Amicis F, Mauro L, Sisci D, Catalano S, Dahlman Wright K, Gustafsson $\mathrm{J}$ and Andò S: Estrogen receptor beta as a novel target of androgen receptor action in breast cancer cell lines. Breast Cancer Res 16: R21, 2014. PMID: 24552459. DOI: 10.1186/ bcr3619

52 Austin D, Hamilton N, Elshimali Y, Pietras R, Wu Y and Vadgama J: Estrogen receptor-beta is a potential target for triple negative breast cancer treatment. Oncotarget 9: 33912-33930, 2018. PMID: 30338035. DOI: 10.18632/oncotarget.26089

53 Mun MJ, Kim J-H, Kim T-H, Hwang J-Y and Jang W-C: Associations between Estrogen Receptor Gene Polymorphisms and Endometriosis. J Korean Soc Menopause 19: 64, 2013. DOI: 10.6118/jksm.2013.19.2.64

54 Ianevski A, He L, Aittokallio T and Tang J: SynergyFinder: a web application for analyzing drug combination dose-response matrix data. Bioinformatics 33: 2413-2415, 2017. PMID: 28379339. DOI: 10.1093/bioinformatics/btx162

55 Lin H-Y, Han H-W, Wang Y-S, He D-L, Sun W-X, Feng L, Wen Z-L, Yang M-K, Lu G-H, Wang X-M, Qi J-L and Yang Y-H: Shikonin and 4-hydroxytamoxifen synergistically inhibit the proliferation of breast cancer cells through activating apoptosis signaling pathway in vitro and in vivo. Chin Med 15: 23, 2020. PMID: 32175001. DOI: 10.1186/s13020-020-00305-1

56 Herman JG and Baylin SB: Gene silencing in cancer in association with promoter hypermethylation. N Engl J Med 349: 2042-2054, 2003. PMID: 14627790. DOI: 10.1056/NEJ Mra023075

57 Bayliss J, Hilger A, Vishnu P, Diehl K and El-Ashry D: Reversal of the estrogen receptor-negative phenotype in breast cancer and restoration of antiestrogen response. Clin Cancer Res 13: 70297036, 2007. PMID: 18056179. DOI: 10.1158/1078-0432.CCR07-0587 
58 Oh AS, Lorant LA, Holloway JN, Miller DL, Kern FG and ElAshry D: Hyperactivation of MAPK induces loss of ERalpha expression in breast cancer cells. Mol Endocrinol 15: 1344-1359, 2001. PMID: 11463858. DOI: 10.1210/mend.15.8.0678

59 Sharma D, Saxena NK, Davidson NE and Vertino PM: Restoration of tamoxifen sensitivity in estrogen receptornegative breast cancer cells: Tamoxifen-bound reactivated ER recruits distinctve corepressor complexes. Cancer Res 66: 63706378, 2006. PMID: 16778215. DOI: 10.1158/0008-5472.CAN06-0402

60 Dikalov SI and Harrison DG: Methods for detection of mitochondrial and cellular reactive oxygen species. Antioxid Redox Signal 20: 372-382, 2014. PMID: 22978713. DOI: 10.1089/ars.2012.4886

61 Son Y, Kim S, Chung H-T and Pae H-O: Reactive oxygen species in the activation of MAP kinases. Methods Enzymol 528: 27-48, 2013. PMID: 23849857. DOI: 10.1016/B978-0-12405881-1.00002-1

62 Zhang J, Wang X, Vikash V, Ye Q, Wu D, Liu Y and Dong W: ROS and ROS-mediated cellular signaling. Oxid Med Cell Longev 2016: 4350965, 2016. PMID: 26998193. DOI: $10.1155 / 2016 / 4350965$

63 Wen C, Wang H, Wu X, He L, Zhou Q, Wang F, Chen S, Huang L, Chen J, Wang H, Ye W, Li W, Yang X, Liu H and Peng J: ROS-mediated inactivation of the PI3K/AKT pathway is involved in the antigastric cancer effects of thioredoxin reductase-1 inhibitor chaetocin. Cell Death Dis 10: 809, 2019. PMID: 31649256. DOI: 10.1038/s41419-019-2035-x

64 Kim J-H, Choi TG, Park S, Yun HR, Nguyen NNY, Jo YH, Jang M, Kim J, Kim J, Kang I, Ha J, Murphy MP, Tang DG and Kim SS: Mitochondrial ROS-derived PTEN oxidation activates PI3K pathway for mTOR-induced myogenic autophagy. Cell Death Differ 25: 1921-1937, 2018. PMID: 30042494. DOI: 10.1038/ s41418-018-0165-9
65 Bekele RT, Venkatraman G, Liu R-Z, Tang X, Mi S, Benesch MGK, Mackey JR, Godbout R, Curtis JM, McMullen TPW and Brindley DN: Oxidative stress contributes to the tamoxifeninduced killing of breast cancer cells: implications for tamoxifen therapy and resistance. Sci Rep 6: 21164, 2016. PMID: 26883574. DOI: $10.1038 /$ srep21164

66 Kawiak A, Domachowska A, Jaworska A and Lojkowska E: Plumbagin sensitizes breast cancer cells to tamoxifen-induced cell death through GRP78 inhibition and Bik upregulation. Sci Rep 7: 43781, 2017. PMID: 28287102. DOI: 10.1038/srep43781

67 Madeo A, Vinciguerra M, Lappano R, Galgani M, GasperiCampani A, Maggiolini M and Musti AM: c-Jun activation is required for 4-hydroxytamoxifen-induced cell death in breast cancer cells. Oncogene 29: 978-991, 2010. PMID: 19935718. DOI: $10.1038 /$ onc. 2009.400

68 Zhang Y, Luo Y-H, Piao X-J, Shen G-N, Wang J-R, Feng Y-C, Li J-Q, Xu W-T, Zhang Y, Zhang T, Wang C-Y and Jin C-H: The design of 1,4-naphthoquinone derivatives and mechanisms underlying apoptosis induction through ROS-dependent MAPK/ Akt/STAT3 pathways in human lung cancer cells. Bioorg Med Chem 27: 1577-1587, 2019. PMID: 30846406. DOI: 10.1016/ j.bmc.2019.03.002
Received October 1, 2020

Revised October 26, 2020

Accepted November 1, 2020 